for conservation globally

Threatened

通
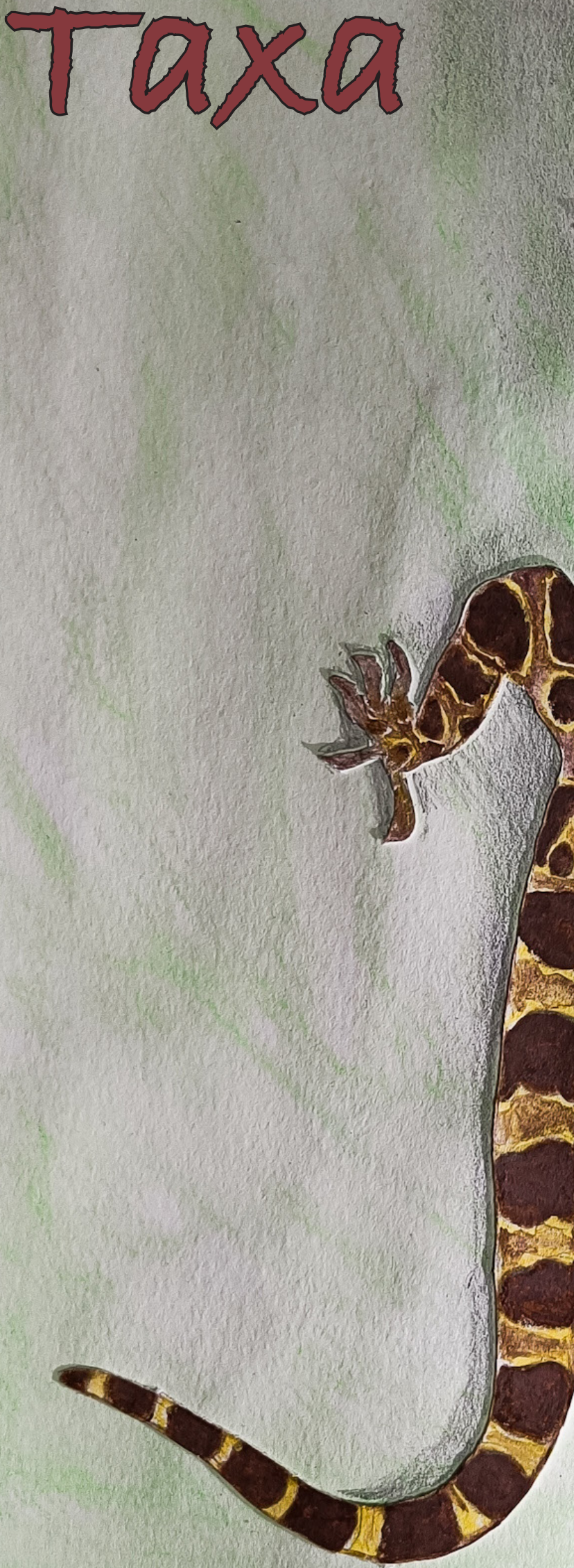

Open Access

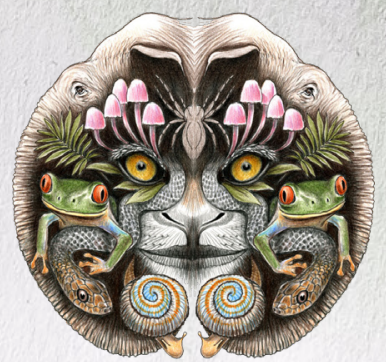

$10.1160 \mathrm{~g} / \mathrm{j}$ ott.2022.14.1.20311-20538 wWw.threatenedtaxa.org

26 January 2022 (Online \& Print) 14(1): 20311-20538 ISSN0974-7907 (Online) ISSN 0974-7893 (Print) 


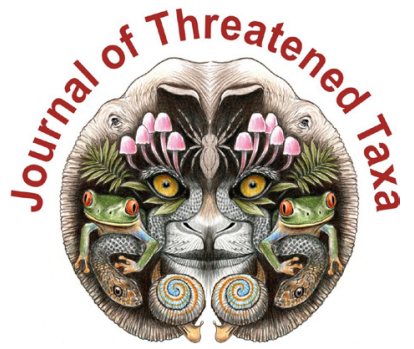

ISSN 0974-7907 (Online); ISSN $0974-7893$ (Print)

Publisher

Host

Wildlife Information Liaison Development Society

www.wild.zooreach.org

Zoo Outreach Organization www.zooreach.org

No. 12, Thiruvannamalai Nagar, Saravanampatti - Kalapatti Road, Saravanampatti, Coimbatore, Tamil Nadu 641035, India

Ph: +91 9385339863 | www.threatenedtaxa.org

Email: sanjay@threatenedtaxa.org

EDITORS

\section{Founder \& Chief Editor}

Dr. Sanjay Molur

Wildlife Information Liaison Development (WILD) Society \& Zoo Outreach Organization (ZOO),

12 Thiruvannamalai Nagar, Saravanampatti, Coimbatore, Tamil Nadu 641035, India

\section{Deputy Chief Editor}

Dr. Neelesh Dahanukar

Noida, Uttar Pradesh, India

\section{Managing Editor}

Mr. B. Ravichandran, WILD/ZOO, Coimbatore, India

\section{Associate Editors}

Dr. Mandar Paingankar, Government Science College Gadchiroli, Maharashtra 442605, India

Dr. Ulrike Streicher, Wildlife Veterinarian, Eugene, Oregon, USA

Ms. Priyanka Iyer, ZOO/WILD, Coimbatore, Tamil Nadu 641035, India

Dr. B.A. Daniel, ZOO/WILD, Coimbatore, Tamil Nadu 641035, India

\section{Editorial Board}

Dr. Russel Mittermeier

Executive Vice Chair, Conservation International, Arlington, Virginia 22202, USA

\section{Prof. Mewa Singh Ph.D., FASc, FNA, FNASc, FNAPsy}

Ramanna Fellow and Life-Long Distinguished Professor, Biopsychology Laboratory, and Institute of Excellence, University of Mysore, Mysuru, Karnataka 570006, India; Honorary Professor, Jawaharlal Nehru Centre for Advanced Scientific Research, Bangalore; and Adjunct Professor, National Institute of Advanced Studies, Bangalore

\section{Stephen D. Nash}

Scientific Illustrator, Conservation International, Dept. of Anatomical Sciences, Health Sciences Center, T-8, Room 045, Stony Brook University, Stony Brook, NY 11794-8081, USA

\section{Dr. Fred Pluthero}

Toronto, Canada

\section{Dr. Priya Davidar}

Sigur Nature Trust, Chadapatti, Mavinhalla PO, Nilgiris, Tamil Nadu 643223, India

\section{Dr. Martin Fisher}

Senior Associate Professor, Battcock Centre for Experimental Astrophysics, Cavendish

Laboratory, JJ Thomson Avenue, Cambridge CB3 OHE, UK

\section{Dr. John Fellowes}

Honorary Assistant Professor, The Kadoorie Institute, 8/F, T.T. Tsui Building, The University of Hong Kong, Pokfulam Road, Hong Kong

\section{Prof. Dr. Mirco Solé}

Universidade Estadual de Santa Cruz, Departamento de Ciências Biológicas, Vice-coordenado do Programa de Pós-Graduação em Zoologia, Rodovia Ilhéus/Itabuna, Km 16 (45662-000)

Salobrinho, Ilhéus - Bahia - Brasil

\section{Dr. Rajeev Raghavan}

Professor of Taxonomy, Kerala University of Fisheries \& Ocean Studies, Kochi, Kerala, India

\section{English Editors}

Mrs. Mira Bhojwani, Pune, India

Dr. Fred Pluthero, Toronto, Canad

Mr. P. Ilangovan, Chennai, India

Web Development

Mrs. Latha G. Ravikumar, ZOO/WILD, Coimbatore, India

\section{Typesetting}

Mr. Arul Jagadish, ZOO, Coimbatore, India

Mrs. Radhika, ZOO, Coimbatore, India

Mrs. Geetha, ZOO, Coimbatore India
Fundraising/Communications

Mrs. Payal B. Molur, Coimbatore, India

Subject Editors 2018-2020

Fungi

Dr. B. Shivaraju, Bengaluru, Karnataka, India

Dr. R.K. Verma, Tropical Forest Research Institute, Jabalpur, India

Dr. Vatsavaya S. Raju, Kakatiay University, Warangal, Andhra Pradesh, India

Dr. M. Krishnappa, Jnana Sahyadri, Kuvempu University, Shimoga, Karnataka, India

Dr. K.R. Sridhar, Mangalore University, Mangalagangotri, Mangalore, Karnataka, India

Dr. Gunjan Biswas, Vidyasagar University, Midnapore, West Bengal, India

\section{Plants}

Dr. G.P. Sinha, Botanical Survey of India, Allahabad, India

Dr. N.P. Balakrishnan, Ret. Joint Director, BSI, Coimbatore, India

Dr. Shonil Bhagwat, Open University and University of Oxford, UK

Prof. D.J. Bhat, Retd. Professor, Goa University, Goa, India

Dr. Ferdinando Boero, Università del Salento, Lecce, Italy

Dr. Dale R. Calder, Royal Ontaro Museum, Toronto, Ontario, Canada

Dr. Cleofas Cervancia, Univ. of Philippines Los Baños College Laguna, Philippines

Dr. F.B. Vincent Florens, University of Mauritius, Mauritius

Dr. Merlin Franco, Curtin University, Malaysia

Dr. V. Irudayaraj, St. Xavier's College, Palayamkottai, Tamil Nadu, India

Dr. B.S. Kholia, Botanical Survey of India, Gangtok, Sikkim, India

Dr. Pankaj Kumar, Kadoorie Farm and Botanic Garden Corporation, Hong Kong S.A.R., China

Dr. V. Sampath Kumar, Botanical Survey of India, Howrah, West Bengal, India

Dr. A.J. Solomon Raju, Andhra University, Visakhapatnam, India

Dr. Vijayasankar Raman, University of Mississippi, USA

Dr. B. Ravi Prasad Rao, Sri Krishnadevaraya University, Anantpur, India

Dr. K. Ravikumar, FRLHT, Bengaluru, Karnataka, India

Dr. Aparna Watve, Pune, Maharashtra, India

Dr. Qiang Liu, Xishuangbanna Tropical Botanical Garden, Yunnan, China

Dr. Noor Azhar Mohamed Shazili, Universiti Malaysia Terengganu, Kuala Terengganu, Malaysia

Dr. M.K. Vasudeva Rao, Shiv Ranjani Housing Society, Pune, Maharashtra, India

Prof. A.J. Solomon Raju, Andhra University, Visakhapatnam, India

Dr. Mandar Datar, Agharkar Research Institute, Pune, Maharashtra, India

Dr. M.K. Janarthanam, Goa University, Goa, India

Dr. K. Karthigeyan, Botanical Survey of India, India

Dr. Errol Vela, University of Montpellier, Montpellier, France

Dr. P. Lakshminarasimhan, Botanical Survey of India, Howrah, India

Dr. Larry R. Noblick, Montgomery Botanical Center, Miami, USA

Dr. K. Haridasan, Pallavur, Palakkad District, Kerala, India

Dr. Analinda Manila-Fajard, University of the Philippines Los Banos, Laguna, Philippines

Dr. P.A. Sinu, Central University of Kerala, Kasaragod, Kerala, India

Dr. Afroz Alam, Banasthali Vidyapith (accredited A grade by NAAC), Rajasthan, India

Dr. K.P. Rajesh, Zamorin's Guruvayurappan College, GA College PO, Kozhikode, Kerala, India

Dr. David E. Boufford, Harvard University Herbaria, Cambridge, MA 02138-2020, USA

Dr. Ritesh Kumar Choudhary, Agharkar Research Institute, Pune, Maharashtra, India

Dr. Navendu Page, Wildlife Institute of India, Chandrabani, Dehradun, Uttarakhand, India

\section{Invertebrates}

Dr. R.K. Avasthi, Rohtak University, Haryana, India

Dr. D.B. Bastawade, Maharashtra, India

Dr. Partha Pratim Bhattacharjee, Tripura University, Suryamaninagar, India

Dr. Kailash Chandra, Zoological Survey of India, Jabalpur, Madhya Pradesh, India

Dr. Ansie Dippenaar-Schoeman, University of Pretoria, Queenswood, South Africa

Dr. Rory Dow, National Museum of natural History Naturalis, The Netherlands

Dr. Brian Fisher, California Academy of Sciences, USA

Dr. Richard Gallon, llandudno, North Wales, LL30 1UP

Dr. Hemant V. Ghate, Modern College, Pune, India

Dr. M. Monwar Hossain, Jahangirnagar University, Dhaka, Bangladesh

Mr. Jatishwor Singh Irungbam, Biology Centre CAS, Branišovská, Czech Republic.

Dr. Ian J. Kitching, Natural History Museum, Cromwell Road, UK

Dr. George Mathew, Kerala Forest Research Institute, Peechi, India

For Focus, Scope, Aims, and Policies, visit https://threatenedtaxa.org/index.php/JoTT/aims_scope
For Article Submission Guidelines, visit https://threatenedtaxa.org/index.php/JoTT/about/submissions
For Policies against Scientific Misconduct, visit https://threatenedtaxa.org/index.php/JoTT/policies_various

continued on the back inside cover 


\title{
Abundance and spatial distribution analyses of Stemonoporus moonii Thwaites (Dipterocarpaceae) - a critically endangered species endemic to Sri Lanka
}

\author{
K.A.M.R.P. Atapattu ${ }^{1}$ (D) H.D.D.C.K. Perera ${ }^{2}$ D, H.S. Kathriarachchi ${ }^{3}$ (i) \& A.R. Gunawardena ${ }^{4}$ (i) \\ ${ }^{1,3}$ Department of Plant Sciences, Faculty of Science, University of Colombo, P.O. Box 1490, Colombo 03, Sri Lanka. \\ ${ }^{2}$ Department of Information and Communication Technology, University of Sri Jayawadenepura, Gangodawila, Nugegoda, Sri Lanka. \\ ${ }^{4}$ Central Environmental Authority, P.O. Box 104, Denzil Kobbekaduwa Mawatha, Sri Jayawardenepura Kotte, Sri Lanka. \\ ${ }^{1}$ priyanwada.atapattu@gmail.com (corresponding author), ${ }^{2}$ dilpuc@gmail.com, ${ }^{3}$ hashi@pts.cmb.ac.lk, ${ }^{4}$ ajiththeja@gmail.com
}

\begin{abstract}
Hora Wel Stemonoporus moonii Thwaites, a plant species endemic to Sri Lanka, is the central focus of this study. Because of its strictly narrow distribution area of fewer than $100 \mathrm{~km}^{2}$ and declining habitat, coupled with a high risk of extinction, it is placed under the 'Critically Endangered' category in International Union for the Conservation of Nature Red List category. A field survey was conducted during February-March 2020 in Walawwe-Watta Wathurana freshwater swamp forest to assess the population status of this species. Global positioning system (GPS) coordinates of individuals were documented. The root collar diameter of plants was measured to differentiate adults. Population size analysis was performed using GeoCAT online software, and a distribution map was prepared using Quantum GIS (QGIS 3). A total of 600 plants were recorded, with $50 \%$ each adult (root collar diameter more than $2.0 \mathrm{~cm}$ ) and young individuals (root collar diameter equal to or less than $2.0 \mathrm{~cm}$ ). The extent of occurrence $(\mathrm{EOO})$ and area of occupancy $(\mathrm{AOO})$ of $S$. moonii were calculated as $0.06 \mathrm{~km}^{2}$ and $4.000 \mathrm{~km}^{2}$, respectively. Two subpopulations of $S$. moonii can be seen within the Walawwe-Watta Wathurana Environmental Protection Area. The findings of the present study support the current IUCN Red List status of S. moonii as Critically Endangered. Even though the existing populations of this species located within a protected area and not presently exposed to major threats, the location is easily accessible and can potentially be affected by anthropogenic pressures and habitat loss. Therefore, this species and the habitat warrant suitable in situ conservation measures. .
\end{abstract}

Keywords: AOO (Area of occupancy), Critically Endangered, EOO (Extent of occurrence), GeoCAT, Hora Wel, IUCN Red List, narrow endemic, QGIS, threat of extinction, Wathurana swamp forest.

Citation: Atapattu, K.A.M.R.P., H.D.D.C.K. Perera, H.S. Kathriarachchi \& A.R. Gunawardena (2022). Abundance and spatial distribution analyses of Stemonoporus moonii Thwaites (Dipterocarpaceae) - a critically endangered species endemic to Sri Lanka. Journal of Threatened Taxa 14(1): 20426-20432. https://doi. org/10.11609/jott.6970.14.1.20426-20432

Copyright: @ Atapattu et al. 2022. Creative Commons Attribution 4.0 International License. JoTT allows unrestricted use, reproduction, and distribution of this article in any medium by providing adequate credit to the author(s) and the source of publication.

Funding: None.

Competing interests: The authors declare no competing interests.

Author details: K.A.M.R.P. ATAPATTU is following masters in Environmental Forestry at the Postgraduate Institute of Agriculture, University of Peradeniya, Sri Lanka. She has experience in plant phylogeny and ecology. She is currently working on species distribution modeling. H.D.D.C.K. PERERA is reading masters in Environmental Management at University of Colombo, Sri Lanka. He works as a visiting lecturer at University of Colombo, and a temporary botanist at University of Jayawardenapura in Sri Lanka. He worked in the National Red List expert panel in Sri Lanka in the years 2012 and 2020. DR. H. S. KATHRIARACHCHI, attached to the Department of Plant Sciences, Faculty of Science, University of Colombo, Sri Lanka. She has expertise in the field of plant molecular systematics and phylogenetics and also forest ecology and restoration. She has undergraduate and postgraduate teaching experience of over 15 years in the field of plant systematics and phylogenetics and engaged in several collaborative research projects with foreign Universities in angiosperm phylogenetics and biodiversity conservation in Sri Lanka. DR. A. R. GUNAWARDENA, currently working as the Director of Research and Development in Central Environment Authority, Sri Lanka. He is an expert in remote sensing and GIS techniques. He has undergraduate and postgraduate teaching experience of over 10 years in the field of remote sensing and GIS techniques.

Author contributions: K.A.M.R.P. Atapattu, H.D.D.C.K. Perera-manuscript writing, field data gathering. H.S.Kathriarachchi-supervising, proof reading A.R.Gunawardena-map preparation.

Acknowledgements: We acknowledge Mr. Rukman Bandara, and Mr. D.P. Kumara for their support. 


\section{INTRODUCTION}

Sri Lanka is a tropical island with a total land area of $65,610 \mathrm{~km}^{2}$ situated in the Indian Ocean. Despite its small size, it has rich ecosystem diversity due to its topography, climatic heterogeneity, and coastal influence (Gunatilleke et al. 2008). It harbors more than 4,100 species of flowering plants, with one-fourth being endemic to the island (Gunatilleke et al. 2008). The southwestern region is the only seasonal ever-wet region in southern Asia, harboring particularly high biodiversity with a high concentration of endemic species. Along with the Western Ghats of India, Sri Lanka is one of the 36 global biodiversity hotspots, and was identified among the eight most significant areas ("hottest hotspots") with a high endemic/area ratio for both vertebrates and plants (Myers et al. 2000).

Walawwe-Watta Wathurana Swamp Forest (WWWSF) is the only freshwater swamp forest in Sri Lanka (CEA 1994; Jayasuriya et al. 2006). Freshwater swamps are described as "nature's kidneys" because they have been found to protect shorelines, prevent floods, clean polluted water and recharge groundwater (CEA 1994). The WWWSF harbors an endemic plant species Stemonoporus moonii Thwaites (Kostermans 1992; CEA 1994; Jayasuriya et al. 2006) that was believed to be extinct in the wild until it was rediscovered in 1979 after a lapse of 160 years (Kostermans 1992; CEA 1994). Stemonoporus moonii is a small, slender tree with a similar appearance to a climber (Image $1 \mathrm{~A}$ ), hence it is locally known as 'Hora Wel' or 'Berumandoru'. It can be distinguished by the long, slender, persistent stipules on the apical branches, crowded leaves, prominent secondary veins and distinct leaf scars (Image 1B) (Rubasingha et al. 2008). The flowers appear singly or in clusters; the corolla is white, with red longitudinal bands on the abaxial side (Image 1C) (Kostermans 1992).

Stemonoporus Thwaites is the most species-rich (27 species) endemic genus of the family Dipterocarpaceae in Sri Lanka. Almost all species of Stemonoporus are categorized as either Endangered or Critically Endangered in the IUCN Red Data Book (Rubasinghe et al. 2008). They are mainly confined to the wet zone and have a well-defined habitat and geographical and ecological range (Dassanayake \& Fosberg 1980). The degradation and fragmentation of natural habitats have had adverse effects on the regeneration and distribution of these threatened species (Ediriweera 2004). Stemonoporus moonii is confined to WWWSF in Sri Lanka. Many studies suggest that narrow endemic species are susceptible to extinction and that these extinction-prone species grow naturally in a narrow geographical area (Kani 2011). For this reason, narrow endemic species are the first to experience the adverse effects of habitat destruction, fragmentation or alteration.

Stemonoporus moonii was assessed as 'Critically Endangered' in the 1998 IUCN Red List of Threatened Species (Ashton 1998). According to the IUCN (2012), the purpose of categorization of species is to create a relative estimate of the likelihood of extinction of the taxon, where the Red List Criteria should be applied to a taxon based on the available evidence such as several individuals, trends, and distribution (Haciogullari et al. 2019). A taxon is categorized as Critically Endangered when the best available evidence indicates that it meets any of the criteria $A$ to $E$ and therefore it is considered to be facing an extremely high risk of extinction (IUCN 2019). The Red List current assessment lists S. moonii as Critically Endangered B1ab(i,ii,iii)+2ab(i,ii,iii). The justification for this categorization is related to its extremely restricted distribution. Both the Extent of occurrence (EOO) and Area of occupancy (AOO) of S. moonii estimated to be less than $10 \mathrm{~km}^{2}$ (MOE 2012).

As per IUCN rules, if an assessment is more than 10 years old, it has to be reassessed. The IUCN category of particular taxa can be changed due to 'genuine' or 'non-genuine' reasons (IUCN 2019). Therefore to assess the status of biodiversity, it is vital to reassess the species periodically. However, no recent published data regarding the current distribution, population size, and threats of S. moonii exist. In this study, the current distribution area and population size of $S$. moonii were determined based on comprehensive and up-to-date assessments.

\section{METHODS}

\section{Study site}

The Walawwe-Watta Wathurana Freshwater Swamp Forest is located in the Kalu Ganga river basin and spread over to 12 ha in the southwestern part of Sri Lanka. It is located on the private land in Bulathsinhala of Damparadugoda, $25 \mathrm{~km}$ inland from Kaluthara District in Western Province, and presently managed by the Walawwe-Watta Plantation Company (Image 2). This forest patch is surrounded by Bulathsinhala and Atura in the north-west, Galketiya in the east, and Pahalawelgama in the west. This land is accessible from the HoranaKalawellawa road through Pahalawelgama and from the Bulathsinhala-Paragoda road. This site is situated along a stream locally known as 'Batapotte ela', which originates 

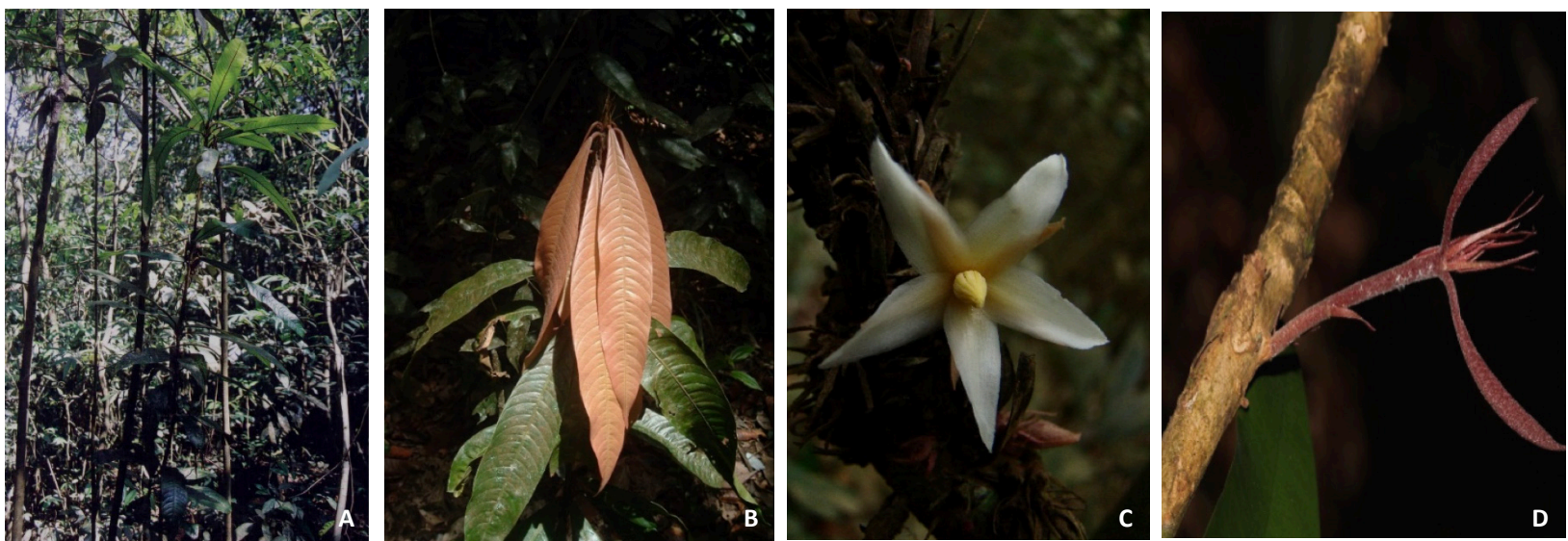

Image 1. Exomorphic features of Stemonoporus moonii: A-Mature plants | B-New foliage | C-Flower | D-New branchlet. @ H.D.D.C.K. Perera.
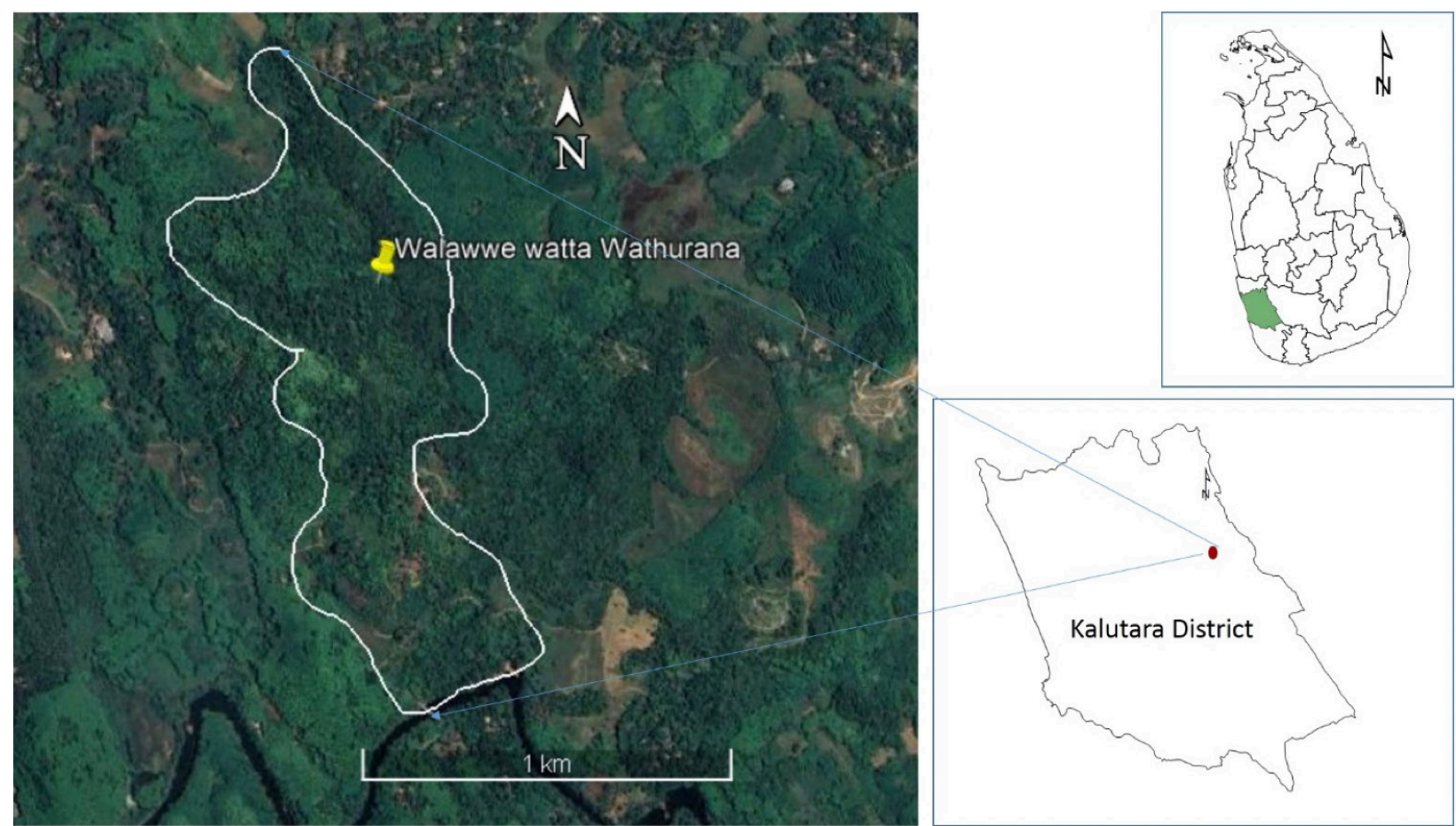

Image 2. The study site in Walawwe-Watta Wathurana Swamp Forest.

at Yatagampitiya and feeds a tributary of the Kalu Ganga. This forest area experiences seasonal flooding twice a year, generally from July to September, and is inundated with up to 3-4 $\mathrm{m}$ of water for 1-2 months. The mean annual rainfall of the area lies between $4,000-5,000$ $\mathrm{mm}$, and the annual temperature is recorded as $27^{\circ} \mathrm{C}$. This area receives rainfall mainly from the south-west monsoon from May to July and the north-east monsoon from October to December (Ashton et al. 2001).

\section{Field surveys}

Field surveys were conducted during FebruaryMarch 2020, and distance sampling methods were used during field surveys. Distance sampling is a widely used technique for estimating the size of a population. For this study the point transect method was used, as it is most appropriate to the rugged and difficult terrain of the site (Haciogullari et al. 2019). In the point transect method, an observer visits randomly-selected points and surveys the species present within a predetermined zone $(5 \mathrm{~m}$ radius in this study). GPS locations of all individuals in the point 
transects were recorded, and root collar diameter was measured. Mature (root collar diameter more than 2.0 $\mathrm{cm}$ ) and immature (root collar diameter equal to or less than $2.0 \mathrm{~cm}$ ) individuals were counted to determine the population size. Additionally, special features such as the presence of flowers, buds, or fruits, whether the plant is dead or dead branches are present, and potential threats were recorded.

\section{Abundance and Spatial Distribution Analyses}

The distribution of S. moonii was analyzed using QGIS 3 (Quantum GIS) software from the obtained locality data. QGIS is an open-source geographic information system. Google satellite image of the study area was overlaid with available locality data of S. moonii. GeoCAT online software was used to calculate the AOO and the EOO; this opensource application can perform rapid geospatial analysis for the Red List assessment. EOO was measured using the quickhull method. AOO was calculated by summation of the area of square grids the species occupies (Bachman et al. 2011). For calculating AOO, a $2 \mathrm{~km}^{2}$ cell size was used, as recommended in the IUCN guidelines (IUCN 2019).

\section{RESULTS}

\section{Abundance and Spatial Distribution}

Walawwe-Watta Wathurana swamp forest was surveyed for the occurrence and abundance of S. moonii. Ten years ago, a few individuals of the species were recorded from the area known as Honaka mountain (H.D.D.C.K. Perera, pers. comm., 22 March 2020). However, in the present study, individuals were recorded only from the WWWSF. Individuals were recorded from the seasonally inundated lands in the forest. In total, 600 individual plants were recorded, including 297 (49.5\%) mature and 303 (50.5\%) immature individuals (Figure 1). Observations were made at the end of the flowering season (January-March), and only one plant was recorded with flowers and eight plants with flower buds. In the study area, S. moonii was commonly associated with the other dominant species, including Garcinia hermonii Kosterm., Dipterocarpus hispidus Thwaites, Cullenia rosayroana Kosterm., Durio zeylanicus Auct., Humboldtia laurifolia Vahl, Quassia indica (Gaertn.) Noot., Macaranga digyna (Wight) Müll.Arg., Ochlandra stridula Thwaites, and Calamus species. No seedlings of S. moonii were observed during the study. Of the 600 individuals, six plants were found dead, one dying, and seven others had dried branches. The individuals were mainly found in two major clusters (1 and 2); 169 in cluster-1 and 431 in cluster-2. Some of the individuals in cluster- 2 were located at the riverbank of Kudu Ganga (Image 3). The EOO and AOO of S. moonii were calculated at $0.057 \mathrm{~km}^{2}$ and AOO $4.000 \mathrm{~km}^{2}$, respectively.

\section{Potential threats}

Although the population is presently not exposed to threats and is still balanced under natural conditions, it could be threatened by various anthropogenic activities. Possible threats are listed below.

Wetlands help maintain freshwater flows within river systems and act as a sponge. The changing land-use patterns and illegal tree felling can lead to flooding in the area and could cause significant detrimental effects on the survival of this species.

Even though Wathurana swamp forest is a protected area, it is easily accessible to nearby villagers who can potentially extract plant parts, collect fuel woods, edible fruits, medicinal plants, poles for agricultural purposes, and timber. The villagers use poles of S. moonii to make trellises for beetle vines.

Due to the modern agricultural practices carried out in the nearby area, the use of chemical fertilizers has increased drastically. Illegal fishing using dynamites is practiced in Batapotte ela stream. Most of these chemicals flow along the water streams of the area, and excess of them tend to deposit in the soil. This may alter the soil composition of the area, which could further impact $S$. moonii population.

People in the vicinity have already altered parts of Wathurana Wetlands to construct new buildings and establish rubber plantations. Such clearing of Wathurana swamp forest areas for agricultural and developmental purposes may directly affect biodiversity.

The soil in this forest area contains high proportions of clay, and mining clay deposits in the area may drastically alter the forest's ecological functions.

The forest clearing and changing land-use patterns in the study area could potentially affect the groundwater table and eventually threaten the existence of the habitat and survival of its flora.

\section{Reassessment of conservation status}

As per the National Red List 2012 of Sri Lanka (MOE 2012), S. moonii was assessed as Critically Endangered based on the criteria B1ab(i,ii,iii)+2ab(i,ii,iii). Based on the newly-available locality data, an up-to-date conservation status can be assessed to determine whether the current conservation status is still valid or if some degree of modification is required. The $\mathrm{AOO}$ and EOO calculated in this study confirm the Critically Endangered status of 


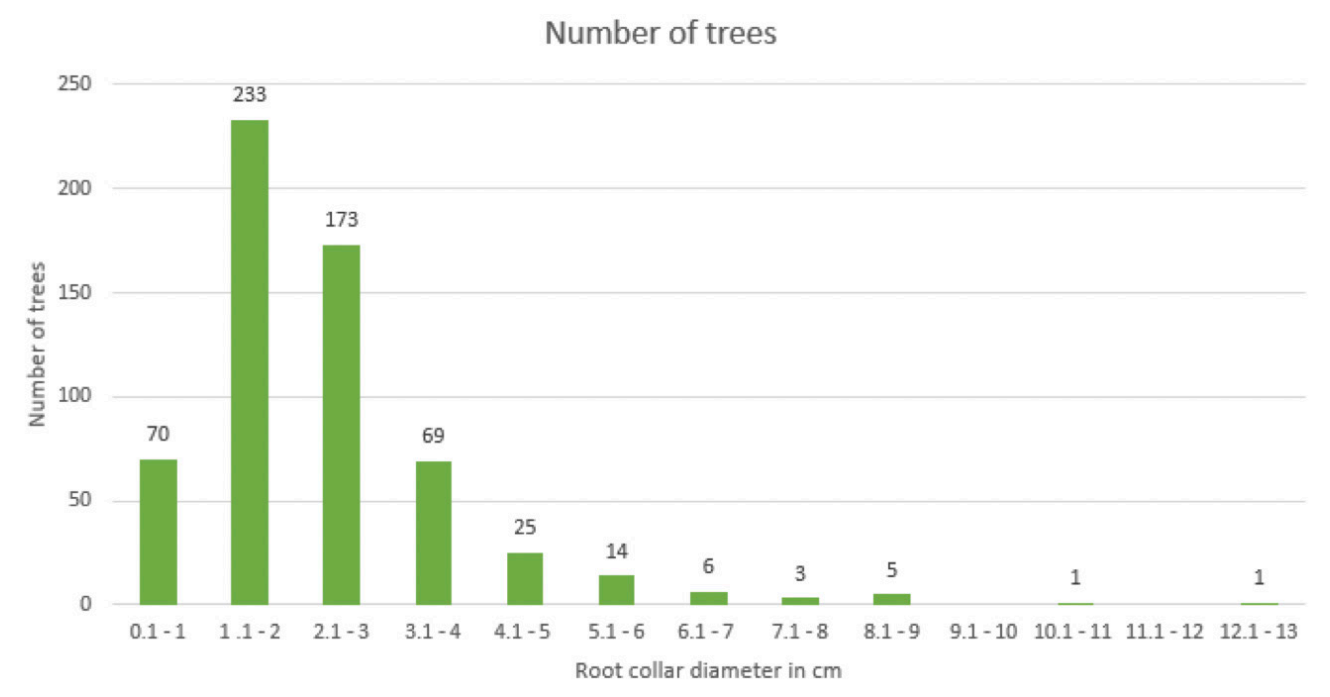

Figure 1. Root Collar Diameter class distribution of individuals of Stemonoporus moonii in the Wathurana swamp forest.
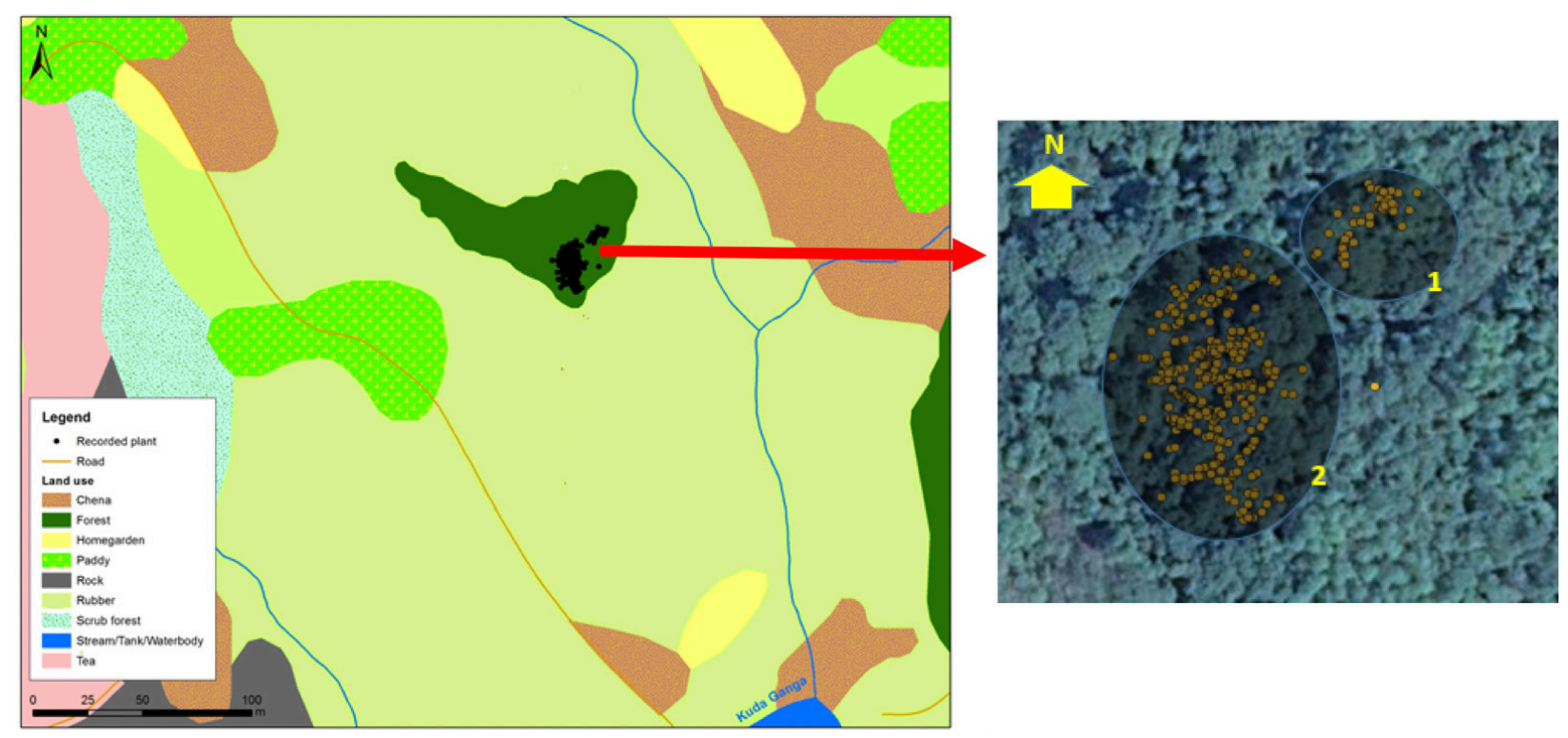

Image 3. Distribution map of Stemonoporus moonii

S. moonii due to its restricted distribution and habitat loss. As a narrow endemic species, S. moonii is strictly confined to the study area, therefore, has a great chance of being extinct in the wild. Currently, it is assessed as B1, which means its EOO is less than $100 \mathrm{~km}^{2}$. The calculated EOO value is $0.057 \mathrm{~km}^{2}$. Therefore, it can be placed in the same category as the current assessment but could also fall under criteria B2 as the $A O O$ is $4 \mathrm{~km}^{2}$, below the $10 \mathrm{~km}^{2}$ threshold. Moving to the next step of the assessment, at least two of the three listed sub-criteria, a, b and c, are to be met. According to the current assessment, it is assessed as ab(i, ii, iii), which means (a) severely fragmented or present in only one location and (b) continuous decline observed, estimated, inferred or projected in (i) extent of occurrence (ii) area of occupancy (iii) area, extent and/or quality of habitat. The survey results suggest that criterion (a) could still be relevant, because it is located in only one location.

In this study, two subpopulations of the species were observed within the protected area with a population density of 9,670 plants/ $\mathrm{km}^{2}$ (600 plants/0.062045 km²). The distance between the two subpopulations was approximately $15 \mathrm{~m}$. The soil types observed in the study area are bog and half bog exhibiting poor drainage compared to the small hillocks. This soil is oxygen and nutrient-poor, and acidic. The seedlings of S. moonii have 
to thrive in such environmental conditions, and these plants prefer seasonally inundated lands in the forest. Also, a strong case could be argued for the inclusion under the $b(\mathrm{i}, \mathrm{ii}, \mathrm{iii})$ category, where declines can be seen in EOO, $\mathrm{AOO}$, and habitat quality. However, the category c(i,ii,iii,iv) could not be included due to the absence of historical data. Moreover, based on the obtained results, the ratio between immature and mature individuals remains nearly $1: 1$. Therefore the decline in the number of mature individuals could not be observed. With this new information, the present reassessment supports retaining the current Critically Endangered status of S. moonii.

\section{DISCUSSION}

One of the main objectives for this study was to assess the population status of S. moonii. Due to its small population size and narrow distribution in Sri Lanka, this has become a threatened species. However, no study has so far been carried out to assess the population size of S. moonii, except for the IUCN Red List evaluation (Ashton 1998). The results of the present study reiterate the Critically Endangered status of this species. Due to the absence of historical records, it is impossible to assess if the population experienced any extreme fluctuations. In this study, the root collar diameter of each individual was measured to find out the proportion of mature and immature individuals. Root collar diameter was the only attainable data from the species because even though it is a tree, it grows like a liana in natural conditions. Hence it is not feasible to measure DBH (Diameter at breast height). Population count proves that the species has no issues with reproduction. The presence of young individuals indicates that seed germination is not an issue, and because of that already balanced population size could be maintained. The equal percentage of mature and young individuals shows that species fecundity is not an issue.

During the survey, no extension or alteration in the flowering period was observed. Usually, plants tend to match their developmental transitions with the best time of year for growth and reproduction to maintain high fitness (Blackman 2017). Flowering time is associated with processes that play a key role in eco-evolutionary dynamics (Franks 2015).

In the study area, S. moonii is commonly associated with other species, including Garcinia hermonii Kosterm., Dipterocarpus hispidus Thwaites, Cullenia rosayroana Kosterm., Durio zeylanicus Auct., Humboldtia laurifolia Vahl, Quassia indica (Gaertn.) Noot., Macaranga digyna (Wight) Müll.Arg., Ochlandra stridula Thwaites, and
Calamus species. In long-lived mixed-species perennial communities, inter-species interactions are more complex. All species share a common environment that interacts with each other, thereby resource competition is high. However, S. moonii was distributed well throughout their habitat. Resource allocation strategies prioritize the persistence of a species, allowing them to persist for a long period in their habitat below their maximum size (Dillon et al. 2019).

The present study reveals that $S$. moonii is still strictly confined to WWWSF probably due to the unique environmental conditions of the area. Freshwater swamps particularly grow on fertile alluvial soils, open to river flooding, and generally have intercommunicating streams with well-mineralized water (Penfound 1952; Aselmann \& Crutzen 1989; CEA 1994; Mitsch \& Gosselink 2000; Gupta et al. 2006). Almost all the individuals of S. moonii were recorded from WWWSF and none of them were recorded from any nearby area. Based on these observations it is clear that $S$. moonii has not extended its geographical region and that it prefers a unique habitat.

Although the different natural and anthropogenic circumstances and processes that promote the loss of species in the area do not cause direct pressure on S. moonii it has a great chance of being extinct from the wild due to its extremely restricted distribution range. People who are involved in cultivating betel (Piper betel), extract these plants as poles to provide the support needed by the betel. Expansion of the agricultural lands and rubber plantations in the nearby area may severely affect their population size. Other than that, a great effect can be caused by the use of chemical fertilizers. Out of the total count, chemical fertilizers are used by $86.67 \%$ of farmers in the area and they have been using them for more than ten years (Siriwardana \& Sangasuman 2018). These chemicals easily wash out and get into water streams in the area. During the flooding season, these chemicals can be deposited on forest lands. S. moonii shows unique features in their distribution only by preferring inundated but most upper margins of the area. Without any doubt, by studying their distribution pattern, it could be said that soil composition and the soil structure cause a great influence on their distribution. If people in the vicinity use these kinds of harmful fertilizers regularly, there is a great chance of altering their distribution, population size, and germination patterns. Many parts of Asia tend to change flow regimes in running waters and consequently impact habitats and species that are sensitive to floods and droughts due to climate change (IPCC 2014). Moreover, the same report on climate change prepared by the Intergovernmental Panel on climate change reveals that 
habitats that depend on seasonal inundation, such as flood plain grasslands and freshwater swamp forests, will be particularly vulnerable (IPCC 2014). Many freshwater habitats are similarly isolated and their restricted-range species may be equally vulnerable.

Due to the impending threats, highly restricted distribution and poor awareness among the local public, urgent measures are required to protect this species. Further studies involving ecological assessment of $S$. moonii covering its population trends, demography, reproductive biology, and population genetics are needed to be carried out. Even though this species is distributed inside the protected area, it is necessary to establish focused in situ and ex situ conservation and management programs. Creating awareness among the general public and the relevant authorities is crucial to curtail unintentional damage to the species and its fragile habitat, and to ensure effective and successful conservation of this unique and highly threatened species.

\section{CONCLUSION}

Analysis of population data collected during the present study supports the existing 'Critically Endangered' status of $S$. moonii. Maintaining a proper ratio between mature and immature individuals under natural conditions reveals that species fecundity is not an issue. Distribution patterns of $S$. moonii show that they prefer seasonally inundating but most upper margins of the forest. Even though S. moonii does not suffer directly from the threats in its natural habitat, it has a great chance of being extinct from the wild because of its narrow distribution. Therefore, suitable conservation measures are urgently needed to protect the populations and habitats of Stemonoporus moonii.

\section{REFERENCES}

Aselmann, I \& P.J. Crutzen (1989). Global distribution of natura freshwater wetlands and rice paddies, their net primary productivity, seasonality and possible methane emissions. Journal of Atmospheric Chemistry 8: 307-358.

Ashton, M.S., C S.V. Gunatilleke, B.M.P. Singhakumara \& I.A.U.N Gunatilleke (2001). Restoration pathway for rain forest in Southwest Sri Lanka: a review of concepts and models. Forest Ecology and Management 154: 409-412.

Ashton, P. (1998). Stemonoporus moonii. The IUCN Red List of Threatened Species. Downloaded on 02 March 2020. https://doi. org/10.2305/IUCN.UK.1998.RLTS.T33439A9784484.en

Bachman, S., J. Moat, A. W. Hill, J. Torre \& B. Scott (2011). Supporting
Red List threat assessments with GeoCAT: geospatial conservation assessment tool. Zookeys 150: 117-126.

Blackman, B.K. (2017). Changing Responses to Changing Seasons: Natural Variation in the Plasticity of Flowering Time. Plant Physiology 173 (1): 16-26.

CEA (1994). Walawwe-Watta Waturana Swamp Forest. Wetland site report. Central Environmental Authority, Colombo 10, Sri Lanka, 54pp.

Dassanayake, M.D. \& F.R. Fosberg (eds.) (1980). A revised handbook to the flora of Ceylon. Amerind Publishing Company, New Delhi.

Dillon, K. T., A. N. Henderson, A. G. Lodge, N. I. Hamilton, L. L. Sloat, B. J. Enquist, C. A. Price, and A. J. Kerkhoff (2019). On the relationships between size and abundance in plants: beyond forest communities. Ecosphere 10(9):e02856. 10.1002/ecs2.2856.

Ediriweera, S. (2004). Conservation Leadership Programme, Preparation of conservation profiles for Stemonoporus species in Sri Lanka. Downloaded on 02 March 2020. http://www. conservationleadershipprogramme.org/project/preparationconservation-profiles-stemonoporus-species-sri-lanka/

Franks, S.J. (2015). The unique and multifaceted importance of the timing of flowering, American Journal of Botany 102(9): 1401-1402.

Gunatilleke, N., R. Pethiyagoda \& S. Gunatilleke (2008). Biodiversity of Sri Lanka. Journal of National Science Foundation Sri Lanka. 36(Special Issue): 25-62.

Gupta, N., A. Anthwal \& A. Bahuguna (2006). Biodiversity of Mothronwala swamp. Doon Valley. Uttaranchal. The Journal of American Science 2: 33-40.

Haciogullari, I., S. Gucel, J. Wayne, O. Ozden (2019). Abundance and spatial distribution analysis of Salvia Veneris: a critically endangered plant species endemic to Cyprus, Biodiversity 20: 98-105.

IPCC (2014). Climate Change 2014: Impacts, Adaptation, and Vulnerability. Part B: Regional Aspects. Contribution of Working Group II to the Fifth Assessment Report of the Intergovernmental Panel on Climate Change, Barros, V.R., C.B. Field, D.J. Dokken, M.D. Mastrandrea, K.J. Mach, T.E. Bilir, M. Chatterjee, K.L. Ebi, Y.O. Estrada, R.C. Genova, B. Girma, E.S. Kissel, A.N. Levy, S. MacCracken, P.R. Mastrandrea, \& L.L. White (eds.). New York, USA, 688 pp.

IUCN (2019). Guidelines for Using the IUCN Red List Categories and Criteria. Version 14. Prepared by the Standards and Petitions Committee. Downloaded on 04 March 2020. http://www.iucnredlist. org/documents/RedListGuidelines.pdf

Jayasuriya, A.H.M., D. Kitchner \& C.M. Biradar (2006). Portfolia of strategic conservation site/ protected area gap analysis in Sri Lanka. Ministry of Environment and Natural resources, Davidson road, Colombo 4, 207 pp.

Kani, I.S I.K. (2011). Rare and endemic species: why are they prone to extinction? Turkey Journal of Botany 35: 411-417.

Kostermans, A.J.G.H. (1992). A hand book of the Dipterocarpaceae of Sri Lanka. The wildlife heritage trust of Sri Lanka.

Mitsch, W.J. \& J.G. Gosselink (2000). Wetlands, $3^{\text {rd }}$ edition. John Wiley \& Sons, Inc., New York.

MOE (2012). The National Red List 2012 of Sri Lanka, Conservation Status of the Fauna and Flora. Ministry of Environment, Colombo, Sri Lanka, viii+476 pp.

Myers, N., R.A. Mittermeier, C.G. Mittermeier, G.A.B. da Fonseca \& J. Kent (2000). Biodiversity hotspots for conservation priorities. Nature 403: 853-858.

Penfound, W.T. (1952). Southern swamp and marshes. Botanical review. 18: 413-466.

Rubasinghe, S.C.K, D.M.D. Yakandawala \& D.S.A. Wijesundara (2008). Phylogenetics of the endemic genus Stemonoporus Thw(Dipterocarpaceae). Journal of National Science Foundation Sri Lanka 36(4): 281-297.

Siriwardana, S.H.S.M. \& V.P. Sangasumana (2018). The Impact of Anthropogenic Intervention on the Walawwe-Watta Wathurana Fresh Water Swamp Forest in Sri Lanka. International Journal of Multidisciplinary Studies 5(2): 130-138. 

Dr. John Noyes, Natural History Museum, London, UK

Dr. Albert G. Orr, Griffith University, Nathan, Australia

Dr. Sameer Padhye, Katholieke Universiteit Leuven, Belgium

Dr. Nancy van der Poorten, Toronto, Canada

Dr. Kareen Schnabel, NIWA, Wellington, New Zealand

Dr. R.M. Sharma, (Retd.) Scientist, Zoological Survey of India, Pune, India

Dr. Manju Siliwal, WILD, Coimbatore, Tamil Nadu, India

Dr. G.P. Sinha, Botanical Survey of India, Allahabad, India

Dr. K.A. Subramanian, Zoological Survey of India, New Alipore, Kolkata, India

Dr. P.M. Sureshan, Zoological Survey of India, Kozhikode, Kerala, India

Dr. R. Varatharajan, Manipur University, Imphal, Manipur, India

Dr. Eduard Vives, Museu de Ciències Naturals de Barcelona, Terrassa, Spain

Dr. James Young, Hong Kong Lepidopterists' Society, Hong Kong

Dr. R. Sundararaj, Institute of Wood Science \& Technology, Bengaluru, India

Dr. M. Nithyanandan, Environmental Department, La Ala Al Kuwait Real Estate. Co. K.S.C.,

Kuwait

Dr. Himender Bharti, Punjabi University, Punjab, India

Mr. Purnendu Roy, London, UK

Dr. Saito Motoki, The Butterfly Society of Japan, Tokyo, Japan

Dr. Sanjay Sondhi, TITLI TRUST, Kalpavriksh, Dehradun, India

Dr. Nguyen Thi Phuong Lien, Vietnam Academy of Science and Technology, Hanoi, Vietnam

Dr. Nitin Kulkarni, Tropical Research Institute, Jabalpur, India

Dr. Robin Wen Jiang Ngiam, National Parks Board, Singapore

Dr. Lional Monod, Natural History Museum of Geneva, Genève, Switzerland.

Dr. Asheesh Shivam, Nehru Gram Bharti University, Allahabad, India

Dr. Rosana Moreira da Rocha, Universidade Federal do Paraná, Curitiba, Brasi

Dr. Kurt R. Arnold, North Dakota State University, Saxony, Germany

Dr. James M. Carpenter, American Museum of Natural History, New York, USA

Dr. David M. Claborn, Missouri State University, Springfield, USA

Dr. Kareen Schnabel, Marine Biologist, Wellington, New Zealand

Dr. Amazonas Chagas Júnior, Universidade Federal de Mato Grosso, Cuiabá, Brasil

Mr. Monsoon Jyoti Gogoi, Assam University, Silchar, Assam, India

Dr. Heo Chong Chin, Universiti Teknologi MARA (UiTM), Selangor, Malaysia

Dr. R.J. Shiel, University of Adelaide, SA 5005, Australia

Dr. Siddharth Kulkarni, The George Washington University, Washington, USA

Dr. Priyadarsanan Dharma Rajan, ATREE, Bengaluru, India

Dr. Phil Alderslade, CSIRO Marine And Atmospheric Research, Hobart, Australia

Dr. John E.N. Veron, Coral Reef Research, Townsville, Australia

Dr. Daniel Whitmore, State Museum of Natural History Stuttgart, Rosenstein, Germany.

Dr. Yu-Feng Hsu, National Taiwan Normal University, Taipei City, Taiwan

Dr. Keith V. Wolfe, Antioch, California, USA

Dr. Siddharth Kulkarni, The Hormiga Lab, The George Washington University, Washington,

D.C., USA

Dr. Tomas Ditrich, Faculty of Education, University of South Bohemia in Ceske

Budejovice, Czech Republic

Dr. Mihaly Foldvari, Natural History Museum, University of Oslo, Norway

Dr. V.P. Uniyal, Wildlife Institute of India, Dehradun, Uttarakhand 248001, India

Dr. John T.D. Caleb, Zoological Survey of India, Kolkata, West Bengal, India

Dr. Priyadarsanan Dharma Rajan, Ashoka Trust for Research in Ecology and the Environment

(ATREE), Royal Enclave, Bangalore, Karnataka, India

\section{Fishes}

Dr. Neelesh Dahanukar, IISER, Pune, Maharashtra, India

Dr. Topiltzin Contreras MacBeath, Universidad Autónoma del estado de Morelos, México

Dr. Heok Hee Ng, National University of Singapore, Science Drive, Singapore

Dr. Rajeev Raghavan, St. Albert's College, Kochi, Kerala, India

Dr. Robert D. Sluka, Chiltern Gateway Project, A Rocha UK, Southall, Middlesex, UK

Dr. E. Vivekanandan, Central Marine Fisheries Research Institute, Chennai, India

Dr. Davor Zanella, University of Zagreb, Zagreb, Croatia

Dr. A. Biju Kumar, University of Kerala, Thiruvananthapuram, Kerala, India

Dr. Akhilesh K.V., ICAR-Central Marine Fisheries Research Institute, Mumbai Research

Centre, Mumbai, Maharashtra, India

Dr. J.A. Johnson, Wildlife Institute of India, Dehradun, Uttarakhand, India

Amphibians

Dr. Sushil K. Dutta, Indian Institute of Science, Bengaluru, Karnataka, India

Dr. Annemarie Ohler, Muséum national d'Histoire naturelle, Paris, France

\section{Reptiles}

Dr. Gernot Vogel, Heidelberg, Germany

Dr. Raju Vyas, Vadodara, Gujarat, India

Dr. Pritpal S. Soorae, Environment Agency, Abu Dubai, UAE.

Prof. Dr. Wayne J. Fuller, Near East University, Mersin, Turkey

Prof. Chandrashekher U. Rivonker, Goa University, Taleigao Plateau, Goa. India

Dr. S.R. Ganesh, Chennai Snake Park, Chennai, Tamil Nadu, India

Dr. Himansu Sekhar Das, Terrestrial \& Marine Biodiversity, Abu Dhabi, UAE
Birds

Dr. Hem Sagar Baral, Charles Sturt University, NSW Australia

Dr. Chris Bowden, Royal Society for the Protection of Birds, Sandy, UK

Dr. Priya Davidar, Pondicherry University, Kalapet, Puducherry, India

Dr. J.W. Duckworth, IUCN SSC, Bath, UK

Dr. Rajah Jayapal, SACON, Coimbatore, Tamil Nadu, India

Dr. Rajiv S. Kalsi, M.L.N. College, Yamuna Nagar, Haryana, India

Dr. V. Santharam, Rishi Valley Education Centre, Chittoor Dt., Andhra Pradesh, India

Dr. S. Balachandran, Bombay Natural History Society, Mumbai, India

Mr. J. Praveen, Bengaluru, India

Dr. C. Srinivasulu, Osmania University, Hyderabad, India

Dr. K.S. Gopi Sundar, International Crane Foundation, Baraboo, USA

Dr. Gombobaatar Sundev, Professor of Ornithology, Ulaanbaatar, Mongolia

Prof. Reuven Yosef, International Birding \& Research Centre, Eilat, Israel

Dr. Taej Mundkur, Wetlands International, Wageningen, The Netherlands

Dr. Carol Inskipp, Bishop Auckland Co., Durham, UK

Dr. Tim Inskipp, Bishop Auckland Co, Durham, UK

Dr. V. Gokula, National College, Tiruchirappalli, Tamil Nadu, India

Dr. Arkady Lelej, Russian Academy of Sciences, Vladivostok, Russia

Dr. Simon Dowell, Science Director, Chester Zoo, UK

Dr. Mário Gabriel Santiago dos Santos, Universidade de Trás-os-Montes e Alto Douro,

Quinta de Prados, Vila Real, Portugal

Dr. Grant Connette, Smithsonian Institution, Royal, VA, USA

Dr. M. Zafar-ul Islam, Prince Saud Al Faisal Wildlife Research Center, Taif, Saudi Arabia

Mammals

Dr. Giovanni Amori, CNR - Institute of Ecosystem Studies, Rome, Italy

Dr. Anwaruddin Chowdhury, Guwahati, India

Dr. David Mallon, Zoological Society of London, UK

Dr. Shomita Mukherjee, SACON, Coimbatore, Tamil Nadu, India

Dr. Angie Appel, Wild Cat Network, Germany

Dr. P.O. Nameer, Kerala Agricultural University, Thrissur, Kerala, India

Dr. Ian Redmond, UNEP Convention on Migratory Species, Lansdown, UK

Dr. Heidi S. Riddle, Riddle's Elephant and Wildlife Sanctuary, Arkansas, USA

Dr. Karin Schwartz, George Mason University, Fairfax, Virginia.

Dr. Lala A.K. Singh, Bhubaneswar, Orissa, India

Dr. Mewa Singh, Mysore University, Mysore, India

Dr. Paul Racey, University of Exeter, Devon, UK

Dr. Honnavalli N. Kumara, SACON, Anaikatty P.O., Coimbatore, Tamil Nadu, India

Dr. Nishith Dharaiya, HNG University, Patan, Gujarat, India

Dr. Spartaco Gippoliti, Socio Onorario Società Italiana per la Storia della Fauna "Giuseppe

Altobello", Rome, Italy

Dr. Justus Joshua, Green Future Foundation, Tiruchirapalli, Tamil Nadu, India

Dr. H. Raghuram, The American College, Madurai, Tamil Nadu, India

Dr. Paul Bates, Harison Institute, Kent, UK

Dr. Jim Sanderson, Small Wild Cat Conservation Foundation, Hartford, USA

Dr. Dan Challender, University of Kent, Canterbury, UK

Dr. David Mallon, Manchester Metropolitan University, Derbyshire, UK

Dr. Brian L. Cypher, California State University-Stanislaus, Bakersfield, CA

Dr. S.S. Talmale, Zoological Survey of India, Pune, Maharashtra, India

Prof. Karan Bahadur Shah, Budhanilakantha Municipality, Kathmandu, Nepal

Dr. Susan Cheyne, Borneo Nature Foundation International, Palangkaraja, Indonesia

Dr. Hemanta Kafley, Wildlife Sciences, Tarleton State University, Texas, USA

\section{Other Disciplines}

Dr. Aniruddha Belsare, Columbia MO 65203, USA (Veterinary)

Dr. Mandar S. Paingankar, University of Pune, Pune, Maharashtra, India (Molecular)

Dr. Jack Tordoff, Critical Ecosystem Partnership Fund, Arlington, USA (Communities)

Dr. Ulrike Streicher, University of Oregon, Eugene, USA (Veterinary)

Dr. Hari Balasubramanian, EcoAdvisors, Nova Scotia, Canada (Communities)

Dr. Rayanna Hellem Santos Bezerra, Universidade Federal de Sergipe, São Cristóvão, Brazil

Dr. Jamie R. Wood, Landcare Research, Canterbury, New Zealand

Dr. Wendy Collinson-Jonker, Endangered Wildlife Trust, Gauteng, South Africa

Dr. Rajeshkumar G. Jani, Anand Agricultural University, Anand, Gujarat, India

Dr. O.N. Tiwari, Senior Scientist, ICAR-Indian Agricultural Research Institute (IARI), New

Delhi, India

Dr. L.D. Singla, Guru Angad Dev Veterinary and Animal Sciences University, Ludhiana, India

Dr. Rupika S. Rajakaruna, University of Peradeniya, Peradeniya, Sri Lanka

Dr. Bahar Baviskar, Wild-CER, Nagpur, Maharashtra 440013, India

Reviewers 2018-2020

Due to pausity of space, the list of reviewers for $2018-2020$ is available online.

The opinions expressed by the authors do not reflect the views of the Journal of Threatened Taxa, Wildlife Information Liaison Development Society, Zoo Outreach Organization, or any of the partners. The journal, the publisher, the host, and the partners are not responsible for the accuracy of the political boundaries shown in the maps by the authors.

Journal of Threatened Taxa is indexed/abstracted in Bibliography of Systematic Mycology, Biological Abstracts, BIOSIS Previews, CAB Abstracts, EBSCO, Google Scholar, Index Copernicus, Index Fungorum, JournalSeek, National Academy of Agricultural Sciences, NewJour, OCLC WorldCat, SCOPUS, Stanford University Libraries, Virtual Library of Biology, Zoological Records.

NAAS rating (India) 5.64
Print copies of the Journal are available at cost. Write to:

The Managing Editor, JoTT,

c/o Wildlife Information Liaison Development Society,

No. 12, Thiruvannamalai Nagar, Saravanampatti - Kalapatti Road,

Saravanampatti, Coimbatore, Tamil Nadu 641035, India

ravi@threatenedtaxa.org 


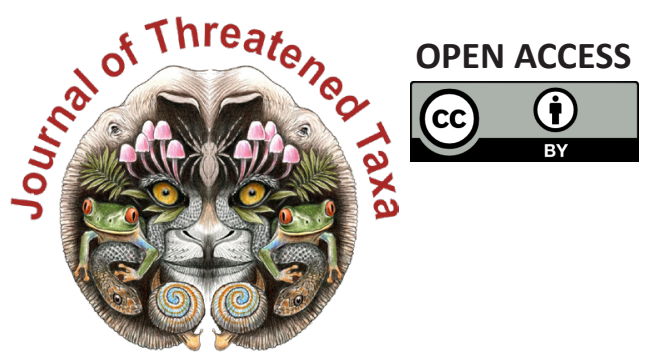

www.threatenedtaxa.org

The Journal of Threatened Taxa (JoTT) is dedicated to building evidence for conservation globally by publishing peer-reviewed articles online every month at a reasonably rapid rate at www.threatenedtaxa.org. All articles published in JoTT are registered under Creative Commons Attribution 4.0 International License unless otherwise mentioned. JoTT allows allows unrestricted use, reproduction, and distribution of articles in any medium by providing adequate credit to the author(s) and the source of publication.

\section{ISSN $0974-7907$ (Online) | ISSN $0974-7893$ (Print)}

\section{January 2022 | Vol. 14 | No. 1 | Pages: 20311-20538 \\ Date of Publication: 26 January 2022 (Online \& Print) DOI: 10.11609/jott.2022.14.1.20311-20538}

Articles

Estimating the completeness of orchid checklists and atlases: a case study from southern Italy

- Antonio Croce, Pp. 20311-20322

A floristic survey across three coniferous forests of Kashmir Himalaya, India - a checklist

- Ashaq Ahmad Dar, Akhtar Hussain Malik \& Narayanaswamy Parthasarathy, Pp. 20323-20345

Associations of butterflies across different forest types in Uttarakhand, western Himalaya, India: implications for conservation planning

- Arun Pratap Singh, Pp. 20346-20370

Comparison of bird diversity in protected and non-protected wetlands of western lowland of Nepal

- Jagan Nath Adhikari, Janak Raj Khatiwada, Dipendra Adhikari, Suman Sapkota, Bishnu Prasad Bhattarai, Deepak Rijal \& Lila Nath Sharma, Pp. 20371-20386

Local hunting practices and perceptions regarding the distribution and ecological role of the Large Flying Fox (Chiroptera: Pteropodidae: Pteropus vampyrus) in western Sarawak, Malaysian Borneo

- Jayasilan Mohd-Azlan, Joon Yee Yong, Nabila Norshuhadah Mohd Hazzrol, Philovenny Pengiran, Arianti Atong \& Sheema Abdul Aziz, Pp. 20387-20399

\section{Communications}

Macrolichens of Mathikettan Shola National Park, Western Ghats: a preliminary investigation with some new records

- Aswathi Anilkumar, Stephen Sequeira, Arun Christy \& S.M. Arsha, Pp. 20400-20405

New distribution record of globally threatened Ocean Turf Grass Halophila beccarii Ascherson, 1871 from the North Andaman Islands highlights the importance of seagrass exploratory surveys

- Swapnali Gole, Prasad Gaidhani, Srabani Bose, Anant Pande, Jeyaraj Antony Johnson \& Kuppusamy Sivakumar, Pp. 20406-20412

An inventory of new orchid (Orchidaceae) records from Kozhikode, Kerala, India - M. Sulaiman, C. Murugan \& M.U. Sharief, Pp. 20413-20425

Abundance and spatial distribution analyses of Stemonoporus moonii Thwaites (Dipterocarpaceae) - a critically endangered species endemic to Sri Lanka - K.A.M.R.P. Atapattu, H.D.D.C.K. Perera, H.S. Kathriarachchi \& A.R. Gunawardena, Pp. 20426-20432

Plant diversity of Point Calimere Wildlife Sanctuary and fodder species grazed by the Blackbuck Antilope cervicapra L.

- Ashutosh Kumar Upadhyay, A. Andrew Emmanuel, Ansa Sarah Varghese \&

D. Narasimhan, Pp. 20433-20443

Raptors observed (1983-2016) in National Chambal Gharial Sanctuary: semi-arid biogeographic region suggestions for parametric studies on ecological continuity in Khathiar-Gir Ecoregion, India

- L.A.K. Singh, R.K. Sharma \& Udayan Rao Pawar, Pp. 20444-20460

Nesting success of Sharpe's Longclaw (Macronyx sharpei Jackson, 1904) around the grasslands of lake Ol'bolossat Nyandarua, Kenya

- Hamisi Ann Risper, Charles M. Warui \& Peter Njoroge, Pp. 20461-20468

Population, distribution and diet composition of Smooth-coated Otter Lutrogale perspicillata Geoffroy, 1826 in Hosur and Dharmapuri Forest Divisions, India - Nagarajan Baskaran, Raman Sivaraj Sundarraj \& Raveendranathanpillai Sanil, Pp. 20469-20477

Utilization of home garden crops by primates and current status of human-primate interface at Galigamuwa Divisional Secretariat Division in Kegalle District, Sri Lanka

- Charmalie Anuradhie Dona Nahallage, Dahanakge Ayesha Madushani Dasanayake, Dilan Thisaru Hewamanna \& Dissanayakalage Tharaka Harshani Ananda, Pp. 2047820487
Revival of Eastern Swamp Deer Rucervus duvaucelii ranjitsinhi (Groves, 1982) in Manas National Park of Assam, India

- Nazrul Islam, Aftab Ahmed, Rathin Barman, Sanatan Deka, Bhaskar Choudhury, Prasanta Kumar Saikia \& Jyotishman Deka, Pp. 20488-20493

Trypanosoma evansi infection in a captive Indian Wolf Canis lupus pallipes - molecular diagnosis and therapy

- Manojita Dash, Sarat Kumar Sahu, Santosh Kumar Gupta, Niranjana Sahoo \& Debarat Mohapatra, Pp. 20494-20499

View Point

COVID-19 and civil unrest undoing steady gains in karst conservation and herpetological research in Myanmar, and an impediment to progress - Evan S.H. Quah, Lee L. Grismer, Perry L. Wood, Jr., Aung Lin \& Myint Kyaw Thura, Pp. 20500-20502

\section{Short Communications}

Morphological characterization and mt DNA barcode of a tiger moth species, Asota ficus (Fabricius, 1775) (Lepidoptera: Noctuoidea: Erebidae: Aganainae) from India - Aparna Sureshchandra Kalawate, K.P. Dinesh \& A. Shabnam, Pp. 20503-20510

Distribution of Smooth-coated Otters Lutrogale perspicillata (Mammalia: Carnivora: Mustelidae): in Ratnagiri, Maharashtra, India

- Swanand Patil \& Kranti Yardi, Pp. 20511-20516

Wildlife at the crossroads: wild animal road kills due to vehicular collision on a mountainous highway in northwestern Himalayan region

- Muzaffar A. Kichloo, Asha Sohil \& Neeraj Sharma, Pp. 20517-20522

Notes

Robiquetia gracilis (Lindl.) Garay-a new record to the flora of Anamalai Hills, Tami Nadu, India

- B. Subbaiyan, V. Ganesan, P.R. Nimal Kumar \& S. Thangaraj Panneerselvam, Pp. 20523-20525

Ipomoea laxiflora H.J. Chowdhery \& Debta (Convolvulaceae): new records for the Western Ghats and semiarid regions

- Sachin M. Patil, Ajit M. Vasava, Vinay M. Raole \& Kishore S. Rajput, Pp. 20526-20529

Counting the cost: high demand puts Bunium persicum (Boiss.) B.Fedtsch. in jeopardy

- Monika Sharma, Manisha Mathela, Rupali Sharma, Himanshu Bargali, Gurinderjit S Goraya \& Amit Kumar, Pp. 20530-20533

First record of Parasitic Jaeger Stercorarius parasiticus (Aves: Charadriiformes: Stercorariidae) from inland freshwater Inle Lake, Myanmar

- Sai Sein Lin Oo, Myint Kyaw, L.C.K. Yun, Min Zaw Tun, Yar Zar Lay Naung, Soe Naing Aye \& Swen C. Renner, Pp. 20534-20536

\section{Book Review}

Capparis of India

- V. Sampath Kumar, Pp. 20537-20538
Publisher \& Host
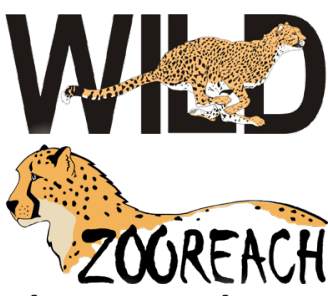

Threatened Taxa 